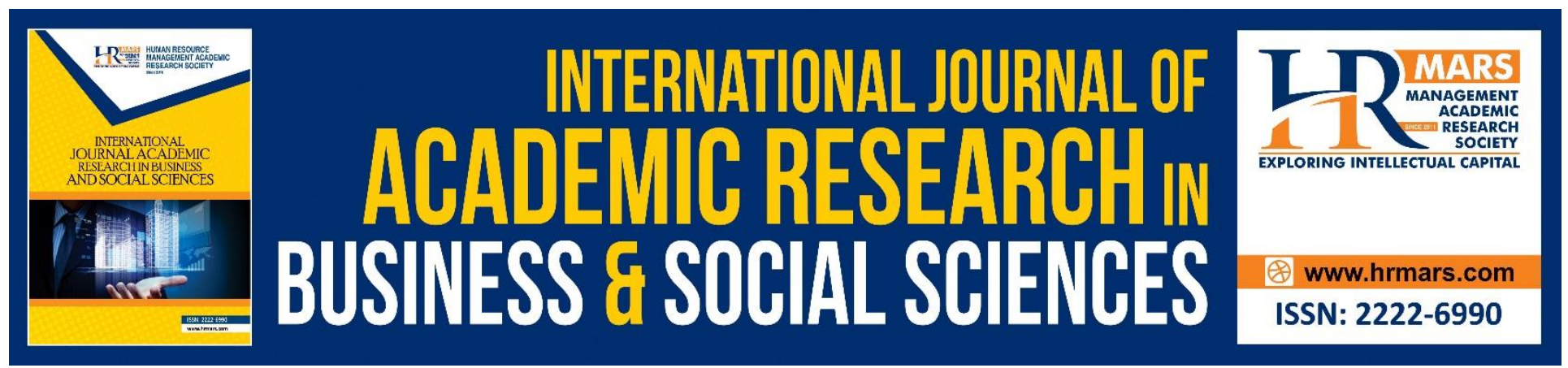

\title{
Competitive Influence Factors among Bumiputera Furniture Manufacturer
}

Nur Syazana Osman, Khairul Aidil Azlin Abd. Rahman, Ahmad Rizal Abd. Rahman, Mohamad Fakri Zaky Ja'afar

To Link this Article: http://dx.doi.org/10.6007/IJARBSS/v8-i7/4386

DOI: $\quad 10.6007 /$ IJARBSS/v8-i7/4386

Received: 28 May 2018, Revised: 21 June 2018, Accepted: 29 June 2018

Published Online: 18 July 2018

In-Text Citation: (Osman, Rahman, Rahman, \& Ja'afar, 2018)

To Cite this Article: Osman, N. S., Rahman, K. A. A. A., Rahman, A. R. A., \& Ja'afar, M. F. Z. (2018). Competitive Influence Factors among Bumiputera Furniture Manufacturer. International Journal of Academic Research in Business and Social Sciences, 8(7), 445-452.

\section{Copyright: (C) 2018 The Author(s)}

Published by Human Resource Management Academic Research Society (www.hrmars.com)

This article is published under the Creative Commons Attribution (CC BY 4.0) license. Anyone may reproduce, distribute, translate and create derivative works of this article (for both commercial and non-commercial purposes), subject to full attribution to the original publication and authors. The full terms of this license may be seen

at: http://creativecommons.org/licences/by/4.0/legalcode

Vol. 8, No. 7, July 2018, Pg. 445 - 452

Full Terms \& Conditions of access and use can be found at http://hrmars.com/index.php/pages/detail/publication-ethics 


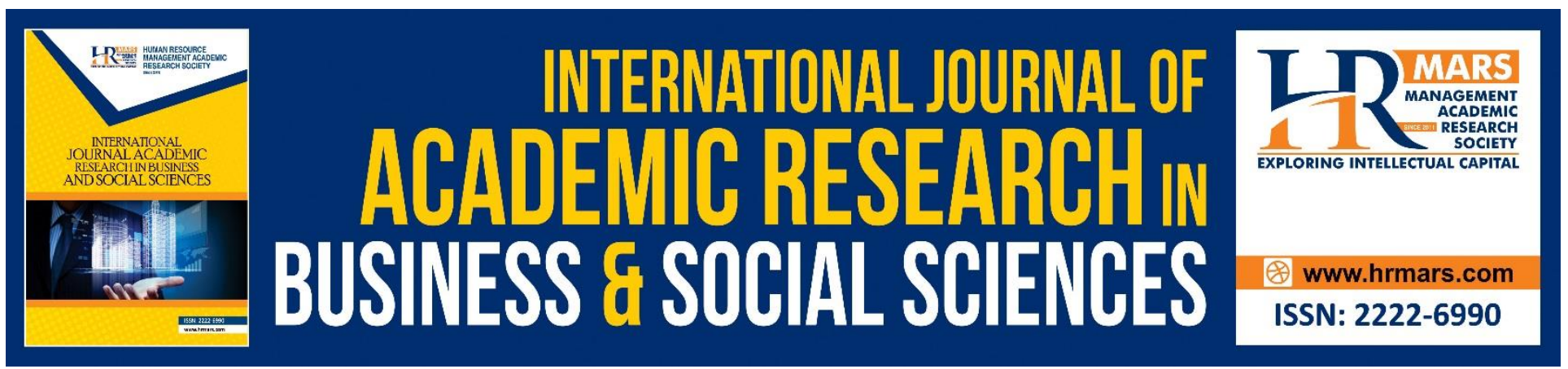

\title{
Competitive Influence Factors among Bumiputera Furniture Manufacturer
}

\author{
Nur Syazana Osman ${ }^{1,2}$, Khairul Aidil Azlin Abd. Rahman¹, Ahmad \\ Rizal Abd. Rahman ${ }^{1}$, Mohamad Fakri Zaky Ja'afar ${ }^{1}$ \\ ${ }^{1}$ Faculty of Design and Architecture, Universiti Putra Malaysia, Malaysia \\ ${ }^{2}$ Universiti Kuala Lumpur, Institute Product Design Manufacturing, Malaysia
}

\begin{abstract}
Factors influencing the decline of export value among Bumiputera furniture manufacturer have been discussed previously. Although the furniture industry contributes the largest number in export value, the participation among Bumiputera manufacturer is very small. This scenario is disrupted because the existing Bumiputera furniture manufacturer is unable to continue their business sustainability due to increase competition or weakness from various aspect of entrepreneurship and other factors. In addition, this industry becomes more worsening with the lack of clusters that can continue the survival of Bumiputera furniture manufacturer. This article seeks to investigate the influential factors and identify the most influential aspects that drive to decline of Bumiputera furniture export. A questionnaire was distributed to more than 30 company and analyzed by using Statistical Package for Social Sciences (SPSS) to test the reliability. The further analyzed was using frequency analysis and descriptive mean test. The findings have important implications for future research direction towards a better performance and capabilities to the organization.
\end{abstract}

Keywords: Malaysia Furniture Industry, Factor of Competitive, Bumiputera Furniture Manufacturer

\section{Introduction}

Malaysia furniture industry generally was started in Muar, Johor and been flourished into exporting giant within the Malaysia sectors. Following with others furniture plant that also flourishing is in Sungai Buloh, Selangor and Pulau Pinang. This furniture industry was started early 1980 and currently has been ranked as eight top producing country and the largest exporter of wooden in the world. Besides that, this industry also was known as the most reputable producers for manufacturing efficiency. 
INTERNATIONAL JOURNAL OF ACADEMIC RESEARCH IN BUSINESS AND SOCIAL SCIENCES Vol. 8, No. 7, July 2018, E-ISSN: 2222-6990 @ 2018 HRMARS

According to Minister Datuk Seri Mah Siew Keong (2017), Malaysia furniture industry contributed significantly to the total export earnings of timber and timber products. The furniture industry's export total in 2015 was valued at RM9.14 billion, which is a 14.1 per cent increase in comparison to RM8 billion the year before. The wooden furniture exports accounted for 80 percent of total furniture exports in 2015 with the value RM7.29 billion and RM7.58 billion in 2016 . This industry shows the growth performance in 2017, with furniture exports increase with 33.8 per cent to RM10.14 billion from the previous year. In addition, by the year 2020, the export timber and timber product aim a target set at MYR55 billion or approximately USD12.5 billion

under NATIP. This amount includes MYR16 billion set for the wood-based furniture industry. Additionally, the Malaysia furniture industry has been as operating as an Original Equipment Manufacturer (OEM) model. The Taiwanese companies were the initial investor in Malaysia and they adopted the OEM model to provide visibility of volume to justify the investment required. Due to the successful model of OEM, the industry has grown tremendously and Malaysia furniture industry is in great demand.

Even though this industry growing rapidly, the furniture manufacturer still has to faced challenge over the past years including an economic meltdown, the offshoring of domestic manufacturing operations and shrinking demand. On globally, the furniture industry faces slower than expected economic recovery, shifting consumer buying preferences, skilled worker shortage, rising labour costs, technology and global competition (P. Tourtellot, 2014; Lucifora \& Origo, 2002). Therefore, the Malaysia furniture industry cannot stay as OEM producers as the rising cost of labor and shortage raw material is affecting the total cost of production compared to Vietnam whose labor cost and raw materials are more accessible to their manufacturing needs.

\section{Literature Review}

In previous research shows the production achievements among the Bumiputera entrepreneurs are still low in this industry especially in an export market. There are more than 3000 furniture entrepreneurs operating in Malaysia and of these approximately 530 of whom are indigenous furniture entrepreneurs and only 25 companies managed to venture into export markets (Zakaria et al., 2012). However, based on the interview with Wan Mohd Hafizi, Assistant Director of Bumiputera Economic Empowerment of MTIB, state only five manufacturers registered under MTIB Bumiputera programmes and this companies are actively contributing to the export market in 2017. These scenarios prove that Bumiputera furniture manufacturer is less competitive particularly in the export market.

Based on the interview with the industry practitioners, Bumiputera furniture manufacturers are more interested to market their product through the 'umbrella scheme' or government contracts. This cause of most manufatcurers are anxious to involve in open market and still tend to operate in a guaranteed market. In addition, Bumiputera furniture manufacturer also failed to exploit the lucrative export market, unlike the non-Bumiputera. According to Associate Professor Dr. Marzuki Ibrahim UiTM (2008), the main factors of the decline participation among Bumiputera in export because they lack technological expertise, secondly lack knowledge in product value chain and thirdly they are lagging in the design aspect. In order them to survive in a competitive marketplace, the local 
INTERNATIONAL JOURNAL OF ACADEMIC RESEARCH IN BUSINESS AND SOCIAL SCIENCES

Vol. 8, No. 7, July 2018, E-ISSN: 2222-6990 (C) 2018 HRMARS

producers especially Bumiputera manufacturer need to offer unique product, functional and premium furniture to cater for the fast-changing global consumer market.

Research Aims

This study investigates how far the factors influence the competitive among Bumiputera furniture manufacturer in Malaysia and also to measure the most factors that contribute to the performance and capabilities in the organization.

\section{Research Question}

It is within the context of the above development that the focus of the research is aimed at the key issues of how the factors influence the competitive of Bumiputera furniture manufacturer in Malaysia? Do the challenge factors help the manufacturer to enhance their performance and capability?

\section{Methodology}

Guided by the extent of literature review and the methodological procedure suggested the scale is developed, tested and purified to measure the Bumiputera furniture manufacturers. The scale was based on the literature where its scale utilized in this study are Likert Scale (5-point scale: 1- strongly disagree to 5- strongly agree). The random sampling was applied involves small, medium and largesized firms. The data of paper were collected through formal and informal face to face interviews. The data collected from the survey was compiled and analyzed using the SPSS software with a relevant statistical test as reported previously.

\section{Result and Discussion}

In spite of the robust growth of Malaysia furniture industry over the past two decades, there is enough evidence to propound the Bumiputera participation in this industry is falling. This study finds some of the key factors of competitive that can be attributed to declining export among Bumiputera manufacturer in furniture industry (figure 1).

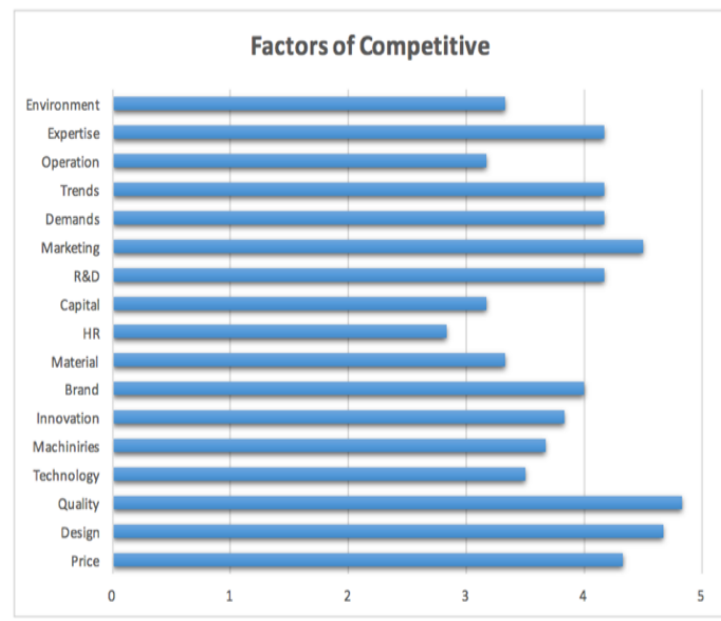

Fig.1: The factors of competitive among Bumiputera furniture manufacturer 
INTERNATIONAL JOURNAL OF ACADEMIC RESEARCH IN BUSINESS AND SOCIAL SCIENCES Vol. 8, No. 7, July 2018, E-ISSN: 2222-6990 @ 2018 HRMARS

\section{a) Quality}

Quality is an important aspect of furniture manufacturing. The lack of highly skilled workers are the main factors affect the quality standard of a product in this industry. All manufacturers are conscious that the ability to produce a certain quality product is an important factor that contributes to sustaining their business performance. Therefore, it is important to the manufacturer to understand the requirement need by the customer and produce quality products by using a good raw material and detail process.

In addition, the quality management (QM) also is the main factors in declining the export value. The poor quality management can be attributed to the non-professional background of Bumiputera entrepreneurs and they place on hands-on approach rather than adopting proven quality control systems (Ministry of Plantation Industries and Commodities Malaysia, 2008).

\section{b) Design and Price}

Design can be defined as the process making things or the product process, and it play a key role in shaping the world with generating new product, system or services. According to Whyte (2005) define design as the purposive application of creativity to all the activities necessary to bring ideas into use either a product or process innovation (Macgregor, Espinach, \& Fontrodona, 2007; Whyte, 2005).

To manufacturer survive in extremely challenging economic condition and remain ahead of the competition abroad, Bumiputera entrepreneurs need to add value in designing innovative product and offer a good service instead of cutting prices. This is due to, the design itself can help the firm improve their organization performance as a strategic tool and also unlock innovation.

\section{c) Marketing}

A functional marketing an organization refers to the concentration of the responsibility for marketing activities (knowledge and skills) within a group specialist in the organization (Moorman, 1999). Marketing skills are the major factor of Bumiputera failure in business and also an export decline (Che Omar \& Mohd Nor Azmi, 2015; Fadzline, Razali, \& Norzanah, 2008). This because most of Bumiputera entrepreneurs do not know how to distinguish the real target market in this furniture industry. Besides understanding the end consumer's value concept and supplying it, entrepreneurs need to be market-oriented where they need to quickly adapt to the ever-changing customer demands.

\section{d) Expertise / Shortage of skilled manpower}

The Malaysia furniture industry today are still facing a problem with expertise and shortage of skilled manpower. According to Chua Chun Chai, President of Malaysia Furniture Council (2016), as much as 373 manufacturers including Bumiputera and non-Bumiputera in nationwide are need of 27,635 foreign workers (Hoh, K. S., 2016). This is caused by the local people are not interested in working in this industry. In addition, besides of shortage skilled manpower, the industry also is facing a problem of lacking talented furniture designers. Through the observartion with the industry players and Zampollo (2015) state most of the designers in the currently market have a limited amount of experiences, skills, and knowledge in the development of design. The shortage of qualified designers is one of the challenges faced by furniture manufacturer to pursue towards the original design manufacturer (ODM) category. 
INTERNATIONAL JOURNAL OF ACADEMIC RESEARCH IN BUSINESS AND SOCIAL SCIENCES Vol. 8, No. 7, July 2018, E-ISSN: 2222-6990 @ 2018 HRMARS

\section{e) Research and development}

Research and development has been considered as very essential for the long-term success of a firm. Thus, investing in R\&D implies generating an important asset for the firm though, this asset can easily disappear if not maintained continuously. Clearly, nowadays scenarios shows most of Bumiputera furniture manufacturer is still lack in R\&D activities which explains the technical inefficiencies, poor machinery layout and also poor product development (NATIP, 2008). For this reason, a firm needs an uninterrupted stream of investment in R\&D and this will help the firms maintain the assets thereby preventing them from becoming extinct overtime (Cuervo-Cazurra \& Annique Un, 2010).

\section{f) Market Demands}

The furniture industry is a huge global business that grown rapidly in recent decades. According to (Kaplinsky, Readman, Memodovic, \& Memedovic, 2009) between the years 1995 and 2000, the trade furniture worldwide grew 36 percent and this study further revealed by 2000, the furniture industry becomes the largest low-tech sector. Although the market demand for this industry is always high, Bumiputera furniture manufacturer is impuissant to meet market demand due to incompetence in product production. This scenario can be seen in figure 2, which most of Bumiputera manufacturer are still floundering in quadrant 1 for this industry.

\begin{tabular}{|c|c|c|}
\hline & $\begin{array}{l}\text { MARKET SHARE } \\
\text { DECREASES }\end{array}$ & $\begin{array}{l}\text { MARKET SHARE } \\
\text { INCREASES }\end{array}$ \\
\hline UNIT VALUE RISES & Quadrant 1 & Quadrant 2 \\
\hline $\begin{array}{l}\text { RELATIVELY TO } \\
\text { INDUSTRY AVERAGE }\end{array}$ & $\begin{array}{l}\text { Failed product } \\
\text { upgrading }\end{array}$ & $\begin{array}{l}\text { Product } \\
\text { upgrading }\end{array}$ \\
\hline UNIT VALUE FALLS & Quadrant 3 & Quadrant 4 \\
\hline $\begin{array}{l}\text { RELATIVELY TO } \\
\text { INDUSTRY AVERAGE }\end{array}$ & $\begin{array}{l}\text { Product and process } \\
\text { downgrading }\end{array}$ & $\begin{array}{l}\text { Process } \\
\text { Competitiveness }\end{array}$ \\
\hline
\end{tabular}

Fig. 2: Schemas for assessing product and process upgrading and downgrading (Kaplinsky \& Readman, 2005)

The quadrant 1 shows the scenario of failed product upgrading as producers are unable to offset rising prices by sufficiently developing attractive product and consequently lose market share.

\section{g) Design Trends}

Design trends are designed that captured by the imagination of consumers and quickly replicated by the competitors. Typically, a trend will cycle per season with the first few months of the year. The business owner and analyst seek to predict what type of designs are likely to trigger a great deal of interest consumer and capitalize on those design before producing. In Malaysia furniture industry, most of the manufacturers are inspired by the western design for product ideas and them incompetent to innovate design with strong differentiation which will give them a competitive edge in the international market.

Most of the manufacturer is unaware that design trends are also an essential part of maintaining and growing market share. Therefore, in order to the manufacturer to stay ahead in the market, the entrepreneurs need to look closely at current industry trends, by seeking clues for variations or changes that may appeal to the buying public. This will help the manufacturers in creating new design 
INTERNATIONAL JOURNAL OF ACADEMIC RESEARCH IN BUSINESS AND SOCIAL SCIENCES

Vol. 8, No. 7, July 2018, E-ISSN: 2222-6990 @ 2018 HRMARS

trends. However, this might need a manufacturer to invest in research and development efforts that involve talented who are capable of taking the information obtained through the analysis.

\section{Conclusion}

Overall, the study contributes to the understanding of Bumiputera furniture manufacturer through the perspectives of the key players in this industry. The expert agreed that design and quality is the most important factor for the furniture manufacturer. Other factors that should be emphasized are marketing skills, design expert/ skilled manpower, market demand, R\&D and also design trends. In consensus, they suggested the Bumiputera furniture manufacturer should cater to both market; domestic and international which determine the success of their firms' internalizations. Nevertheless, all of these factors are interrelated and neither one of them can be eliminated.

\section{Acknowledgments}

The authors wish to thank the following people for fruitfuil discussions. My colleagues and the anonymous audience from the previous conference are thanked for their valuable comments and ideas on the presentation of the paper, its contribution to the refinement of the contextualization approach for the study. This support is gratefully acknowledged.

\section{References}

1. Che Omar, C. M. Z., \& Mohd Nor Azmi, N. (2015). Factors Affecting the Success of Bumiputera Entrepreneurs in Small and Medium Enterprises ( SMEs) in Malaysia. International Journal of Management Science and Business Administration, 1(9), 40-45. http://doi.org/dx.doi.org/10.18775/ijmsba.1849-5664-5419.2014.19.1004

2. Cuervo-Cazurra, A., \& Annique Un, C. (2010). Why some firms never invest in formal R\&D. Strategic Management Journal, 31(7), 759-779. http://doi.org/10.1002/smj.836

3. Fadzline, M. P., Razali, A., \& Norzanah, M. (2008). The Dilemma of Bumiputera Furniture Entrepreneurs. 2008ifcx International Furniture Conference and Exhibition.

4. Hoh, K. S. (2016, October 27). Press Digest -Labour shortage faced by furniture manufacturers very worrying. Retrieved June 28, 2018, from $h t t p: / / w w w . t h e s u n d a i l y . m y / n e w s / 2041288$

5. Inn, T.K. (2016, June 17). Growing property sector to benefit furniture industry- Business NewsThe Stare Online. Retrieved from; https://www.thestar.com.my/business/businessnews/2016/06/18/growing-property-sector-to-benefit-furniture-industry/

6. Kaplinsky, R., \& Readman, J. (2005). Globalization and upgrading: What can (and cannot) be learnt from international trade statistics in the wood furniture sector? Industrial and Corporate Change, 14(4), 679-703. http://doi.org/10.1093/icc/dth065

7. Kaplinsky, R., Readman, J., Memodovic, O., \& Memedovic, O. (2009). Upgrading strategies in global furniture value chains. UNIDO Research and Statistics Branch Working Paper, 9, 0-7. Retrieved from http://oro.open.ac.uk/12866/

8. Lucifora, C., \& Origo, F. (2002). The economic cost of the skill gap in Europe, 2002(August).

9. Macgregor, S. P., Espinach, X., \& Fontrodona, J. (2007). Social Innovation: Using Design To Generate Business Value Through Corporate Social Responsibility. International Conference on Engineering Design, Iced'07, 10(August), 1-12.

10. Malaysia Timber Industry Board (MTIB). (2009).

11. Ministry of Plantation Industries and Commodities Malaysia (2008). National Timber Industry Policy 2009-2020 (2009th ed.). 
INTERNATIONAL JOURNAL OF ACADEMIC RESEARCH IN BUSINESS AND SOCIAL SCIENCES

Vol. 8, No. 7, July 2018, E-ISSN: 2222-6990 @ 2018 HRMARS

12. Mohammad Yusof, N. A., \& J. F. (2018, March 8). Furniture exports at RM10.14bil in 2017. Retrieved June 28, 2018, from https://www.nst.com.my/business/2018/03/343070/furnitureexports-rm1014bil-2017

13. Moorman, C. (1999). The role of marketing. Journal of Marketing, 63(1999), 180-197. http://doi.org/10.2307/1252111

14. P. Tourtellot (2014, October 23). Furniture industry at critical turning point. Retrieved June 28, 2018, from http://www.furnituretoday.com/article/492944-furniture-industry-critical-turningpoint

15. Whyte, J. (2005). Management of creativity and design within the firm. Thought A Review Of Culture And Idea, 1-36.

16. Zakaria, S., Mohd, T., Tuan, R., Kamaruzaman, N., Abdulatiff, H. J., \& Yaacob, M. R. (2012). Exploring the creativity of bumiputera 's furniture entrepreneurship. Elixir Mgmt. Arts 51 (2012) 10750-10758, 51, 10750-10758.

17. Zampollo, F. (2015). Design - Driven Innovation VS User - Centred Design . Not Really ..., 13. 